\title{
Update on Management of Fungal Keratitis
}

\author{
Orapin Anutarapongpan ${ }^{1,2}$ and Terrence P. O'Brien ${ }^{1^{*}}$ \\ ${ }^{1}$ Bascom Palmer Eye Institute of Palm Beach Gardens, Miller School of Medicine, University of Miami, Miami, FL, USA \\ ${ }^{2}$ Department of Ophthalmology, Faculty of Medicine, Srinagarind Hospital, Khon Kaen University, Khon Kaen, Thailand
}

"Corresponding author: Terrence P. O’Brien, Bascom Palmer Eye Institute of Palm Beach Gardens, Miller School of Medicine, University of Miami, Miami, FL, USA, Tel: (561) 515-1544; Fax: (561) 355-8600; E-mail: tobrien@med.miami.edu

Received date: June 02, 2014, Accepted date: September 26, 2014, Published date: October 03, 2014

Copyright: () 2014 Anutarapongpan O, et al. This is an open-access article distributed under the terms of the Creative Commons Attribution License, which permits unrestricted use, distribution, and reproduction in any medium, provided the original author and source are credited.

Keywords Perforation; Fusarium spp; Keratitis; Ophthalmic

\section{Introduction}

Fungal keratitis is one of the major causes of visual loss and blindness [1,2], especially in developing countries, characterized by ulceration, suppuration, destruction of and even perforation of corneal tissues [3]. The most common causative pathogens are Fusarium spp, Aspergillus spp and Candida albicans varying geographically among areas. Fusarium spp and Aspergillus spp are common in tropical and subtropical eastern countries and southern US [4]. Candida albicans is more common in temperate areas such as the northern US [4]. Recent outbreaks of Fusarium keratitis associated with multipurpose contact lens solutions have increased the numbers of contact lens associated fungal keratitis. The most common risk factor in many studies is ocular trauma, particularly with vegetative material. Other risk factors include contact lens use, ocular surgery, ocular surface disease, previous use of topical corticosteroids, a compromised immune system, and tropical, humid climates. Fungal keratitis remains a diagnostic challenge and a difficult therapeutic problem for ophthalmic clinicians because these fungal infections of the cornea frequently result in corneal melting, visual impairment and devastating ocular damage if they are not diagnosed early and treated promptly and effectively $[5,6]$. There is a need for more sensitive and specific diagnostic methods for early detection of fungal keratitis. More effective antifungal agents in terms of antifungal efficacy and corneal tissue penetration are desired for improved clinical outcomes. This review provides an update on management of fungal keratitis.

\section{Diagnosis}

Awareness of this condition and developing a clinical suspicion are important keys for early diagnosis. The predisposing risk factors (Table 1), together with the clinical appearance on slit-lamp biomicroscopic examination such as elevated firm slough; hyphate branching ulcers, irregular feathery margins, a dry rough texture, pigmented lesion, and satellite lesions are significant findings suggestive for fungal keratitis $[4,7,8]$. However in more advanced cases, fungal keratitis may present with an endothelial plaque, hypopyon, ring infiltration, suppurative stromal keratitis, and possible corneal perforation.

To confirm the diagnosis before commencing initial treatment, corneal scraping is indicated, using a sterile blade to scrape along the edges of the ulcerated cornea. The material gathered is placed on clean microscope slides. Staining tests are simple, rapid and inexpensive methods to facilitate diagnosis. For example, a $10 \%$ potassium hydroxide $(\mathrm{KOH})$ wet mount, allows direct visualization of the fungal cell wall by partially digesting the proteinaceous components such as host cells and stromal collagen but leaving polysaccharide containing fungal cell walls intact.

\begin{tabular}{|l|}
\hline Ocular trauma, particularly with vegetative material \\
\hline Contact lens use \\
\hline Ocular surgery \\
\hline Ocular surface disease \\
\hline Previous use of topical corticosteroid \\
\hline Compromised immune system ( HIV, diabetes) \\
\hline Tropical and humid climates \\
\hline
\end{tabular}

Table 1: Risk Factors for Fungal Keratitis

Gram stain is used to identify bacteria and classify them into Gramnegative and Gram-positive groups; it can also be used to identify fungi in $35 \%$ to $90 \%$ of culture positive cases $[9,10]$. Sensitivity and specificity of $\mathrm{KOH}$ preparation has been reported to range from $62 \%$ to $99 \%$ and $73 \%$ to $99 \%$ retrospectively [9,11-13]. Moreover, Giemsa stain and Gomori methenamine silver stain are useful to highlight hyphal fungal fragments. Calcofluor white stain binds to chitin and cellulose in fungal cell wall and demonstrates bright green fluoresces under ultraviolet light. Combined staining either with Giemsa or Calcofluor white stain along with $\mathrm{KOH}$ preparation can improve diagnostic accuracy. Culture on multiple selective culture media such as Sabouraud's agar, blood agar, chocolate agar, brain-heart infusion/ gentamicin, and thioglycollate broth was required for identification of the causative pathogen as a gold standard diagnosis. In cases epithelium intact, corneal material can be obtained by using a sterile silk suture (6-0 to 8-0) pass through the level of infiltrated cornea and subsequently transfer this suture sterilely onto culture media $[14,15]$.

\section{Corneal biopsy}

In culture negative cases demonstrating progressive suspected microbial keratitis despite intensive antimicrobial therapy, corneal biopsies should be considered [16]. Corneal biopsy may have an important role to confirm the diagnosis of fungal keratitis because histopathological evaluation of infected cornea has found that fungi often present deep in the corneal stroma [17]. Culture of the biopsy tissue specimen is practical and may change antimicrobial therapy, resulting in improved clinical outcomes. Multiple surgical techniques have been described, for example; using a sterile blade, microtrephineassisted, dermatological skin punch of a specified diameter or femtosecond laser-assisted corneal biopsy [14,16,18-20]. 


\section{Imaging modalities}

New technology has provided more rapid real time and noninvasive tools for detection of microbial keratitis, especially fungal keratitis. The confocal microscope, using point illumination and a spatial pinhole to eliminate out-of-focus light, allows in vivo examination of the full thickness of cornea [21]. There are many types of confocal microscopes, from first generation to more advanced generation including Tandem scanning confocal microscope (TSCM), slit scanning confocal microscope (SCCM), laser scanning confocal microscope (LSCM). TSCM, no longer commercially available, significantly limits light transmission which produces poor contrast images compared to other confocal microscopes. SCCM such as Confoscan 3 and Confoscan 4 (Nidek Technologies), have a wide slit aperture that allows more light transmission, which improves brightness and contrast of the images and increases depth of field. The Heidelberg retina tomograph rostock corneal module laser scanning confocal microscope (HRT-II/RCM and HRT-III/RCM), using laser light at $670 \mathrm{~nm}$ wavelength, provided high-contrast, high-quality images [22]. Many studies showed that it provides high sensitivity and specificity ranging from $88.3-94 \%$ and $78-91.1 \%$ [23-25], respectively. Although cultures and smears are standard diagnostic methods for fungal keratitis, these microbiology techniques require considerable time and expertise. Definitive identification of causative pathogens is required for start of initial antifungal treatment. This emerging technology may provide rapid and useful diagnosis, especially in the following conditions such as deep stromal infiltrates not accessible to corneal scrapings: long term antifungal therapy while organisms continue to be present in the deep stroma, after intracorneal ring segment implantation, after incisional refractive surgery or LASIK [23]. Moreover IVCM can be used to monitor the response to treatment of fungal keratitis. Limitations of confocal microscope are limited accessibility, cost and quality of images depending highly on the experience of the operating technician.

\section{Molecular diagnostic techniques}

Molecular diagnosis with high sensitivity and specificity has attracted more and more attention than the conventional mycological techniques. A variety of molecular techniques based on amplification, such as nested PCR [9,26], real-time PCR [27-29], loop-mediated isothermal amplification [30,31], and nucleic acid hybridization [32]. PCR is an ideal diagnostic method for fungal keratitis because only a small sample material is required to perform the test. Recently, almost all studies targeted the fungal ribosomal DNA regions, such as $18 \mathrm{~S}$ rRNA, 28S rRNA and internal transcribed spacer regions as amplification targets [26]. Several studies have reported to detect fungal DNA in the corneal sample by PCR-based amplification using universal (panfungal) primers or more specific primers, followed by identification of the fungus by sequencing of the amplified fungal DNA; other studies have reported molecular identification of fungi isolated in culture from corneal scrapings [26]. The advantage is higher detection rates and identification of specific fungal pathogens $[33,34]$ this may lead to the use of PCR as the reference standard for diagnosis of fungal keratitis. However, some investigators mentioned that non-pathogenic microorganisms could be amplified by this technique leading to confusion about the actual diagnosis [35]. The cost of performing the PCR may be more expensive than using conventional microbiological methods and require more specific materials and instrumentation. These methods can possibly be applied for patients in whom conventional tests do not yield positive results.
Nest PCR is a very sensitive method but false-positive results are a problem $[9,36]$. Currently, real-time PCR is the fastest method of the PCR-based techniques [29]; however, the method normally requires a sophisticated instrument and a well-trained medical staff. Nucleic acid hybridization is another molecular method, employing a DNA probe that determines whether a particular organism is present or not. It effectively localizes the DNA and RNA of infectious agents in tissues and no DNA extraction is required [36]. Although this assay is rapid and easy to perform but the sensitivity is lower than other molecular techniques $[37,38]$.

Molecular diagnostic techniques, providing higher sensitivity, greater rapidly were expected to have an important role on the diagnosis of fungal keratitis in the future [32,39].

\section{Treatment}

Once diagnosis of fungal keratitis is confirmed, medical treatment should begin immediately. The causative fungal pathogen(s) can be properly identified through laboratory analysis of corneal scraping, vital staining, and microbial culture. Early diagnosis and prompt, effective treatment are important and may prevent loss of vision and blindness for the patient. Fungal keratitis usually requires a prolonged course of treatment with antifungal agent(s) because of the fungistatic activity and poor bioavailability of these agents.

\section{Polyenes}

Polyenes bind directly to fungal membrane sterols (especially ergosterol) and create ionic membrane channels, causing osmotic disruption by an increase in membrane permeability. Polyenes also interfere with fungal membrane-associated oxidative enzyme function. Both actions lead to cell death [40-42]. Natamycin, being the only commercially available topical ophthalmic antifungal preparation, has a board-spectrum of activity against filamentous organisms, such as Fusarium spp, Aspergillus spp, Curvularia spp. It is available as a topical $5 \%$ suspension and is a first-line therapy for fungal keratitis. Amphotericin B, another polyene, is active aganist yeast and a firstline treatment of keratitis caused by Candida spp, commonly administered as a topical $0.15-0.30 \%$ solution [43]. Moreover, intracameral, intrastromal, intravitreal, and subconjuctival amphotericin B injection have been reported as adjuvant treatment. These polyene agents are large molecules with high molecular weight and have limited penetration into the deep corneal stromal and the anterior chamber. Intracameral, intrastromal, and subconjuctival amphotericin B injection have not been evaluated extensively. However, a few clinical trials have reported favorable results for treatment of fungal keratitis. Shao $\mathrm{Y}$ et al. evaluated the therapeutic effect of intracameral amphotericin B injection compared to $0.15 \%$ topical amphotericin B in 60 patients with fungal keratitis. The comparison revealed that intracameral amphotericin B injection leads to faster healing of keratomycosis and reduced time to disappearance of hypopyon [44]. Yoon $\mathrm{KC}$ et al. reported that intracameral amphotericin B injection combined with conventional treatment was better than conventional treatment alone in reducing time to disappearance of hypopyon and final improvement [45]. Furthermore, Intracameral amphotericin B has adjuvant effect in cases of fungal keratitis unresponsive to conventional treatment [46]. One case report demonstrated that intrastromal combined with intravitreal amphotericin B injection can successfully eradicate recurrent fungal keratitis with endophthalmitis caused by Candida glabrata [47]. The ocular toxicity study showed that Intrastromal injection of 
Page 3 of 8

amphotericin B at concentration of less than $10 \mu \mathrm{g}$ per $0.1 \mathrm{ml}$ was safe in the rabbit corneas [48]. Subconjuctival amphotericin B therapy has also been reported in a small case series as an adjunctive treatment in patients with severe fungal keratitis but subconjunctival nodules and necrosis are possible adverse effects $[49,50]$.

\section{Azoles}

Azoles primarily target the ergosterol biosynthesis pathway by inhibition of cytochrome P450 (CYP)-dependent C-14a demethylase converted lanosterol to ergosterol, an essential component of the fungal cell wall [40]. Certain triazoles, for example; fluconazole, itraconazole and voriclonazole, may interact with secondary targets in the ergosterol biosynthesis pathway but an affinity for these secondary targets varies among the agents and pathogen genus [51]. Among species the triazoles varies in their primary target (14a demethylase) and secondarily targets inhibition in the ergosterol biosynthesis pathway, which may cause the differences in antifungal activity in this class. Azoles are classified into 2 groups, imidazoles including econazole, miconazole, and ketoconazole; triazoles including fluconazole, itraconazole, voriconazole, and posaconazole. Ketoclonazole is the first successful orally absorbable broad-spectum antifungal azole, currently used as an oral pill and 1-2\% ketoclonazole suspension topical form in treatment of patients with fungal keratitis [51-54]. 1\% Miconazole and subconjuctival miconazole $(10 \mathrm{mg} / 0.5 \mathrm{ml})$ have been reported in 2 case series as the treatment for fungal keratitis cause by filamentous fungi and Candida [55,56]. 2\% econazole was found to be as effective as $5 \%$ natamycin in a randomized controlled trial in 112 fungal keratitis patients but combined both of them have not gain more benefit $[57,58]$. Itraconazole is given by oral $(200-400$ $\mathrm{mg}$ /day) or $1 \%$ suspension topical form in therapy of ophthalmic mycoses [59-61]. Subconjunctival or topical fluconazole adding to topical natamycin showed positive results in treating severe fungal keratitis [62,63]. Subconjuctival fluconazole in combination with topical amphotericin B has been reported to provide better outcomes as well $[64,65]$. Otherwise, topical fluconazole alone should be used with caution because an extremely poor clinical response with monotherapy in one randomized clinia trial for fungal keratitis [66-68]. Voriconazole, a new generation triazole antifungal agent, possesses a very broad spectrum of activity against dermatophytes, yeast, and molds. Many studies showed adequate aqueous and vitreous concentration after topical and oral voriconazole treatment for various fungal pathogens $[69,70]$. A large study assessing filamentous fungal susceptibility using ocular isolates from 221 keratitis cases in south India disclosed overall that organisms had lower MICs to voriconazole than to natamycin, but Fusarium isolates were less susceptible to voriconazole and Aspergillus flavus isolates appeared to have lower susceptibility to natamycin compared to other organisms [71]. Moreover, a number of case series showed promise for delivering successful management of mild to severe fungal keratitis with topical, intrastromal, and oral voriconazole [72-75]. In contrast, several randomized clinical trials did not find a significant difference in treatment outcomes between voriconazole and natamycin [76-78]. A large randomized double-masked control trial called The Mycotic Ulcer Treatment Trial (MUTT) enrolled 368 patients to compare topical voriconazole $1 \%$ versus topical natamycin in the treatment of filamentous fungal keratitis. This study found that topical natamycin is superior to topical voriconazole and voriconazole monotherapy is not recommend for filamentous fungal keratitis [79]. Sharma $\mathrm{N}$ et al. found that topical voriconazole could potentially add benefit to topical natamycin in recalcitrant fungal keratitis [80]. Ramakrishnan et al. reported a 50\% successful treatment rate in combining topical, oral, and/or intracameral, intrastromal voriconazole with natamycin $[81,82]$. Posaconazole is another new triazole agent. Topical and oral posaconazole have been used in therapy of fungal keratitis, with one case series reporting successful treatment of Fusarium keratitis, resistant to voriconazole $[83,84]$.

\section{Echinocandins}

Echinocandins, synthetic lipopeptides, are derived from fermentation products from several different fungi. These agents disrupt cell wall synthesis by inhibiting $\beta 1,3-\mathrm{D}$-glucan synthase and possess a narrow antifungal spectrum that is restricted to Candida $s p p$ and some Aspergillus spp. Echinocandins, include caspofungin, micafungin, and anidulafungin. Recently, one case reported by Hurtado-Sarrio et al. demonstrated successful treatment of Candida albican keratitis refractory to voriconazole using topical caspofungin [85]. Tu EY reported 3 cases of Alternaria keratitis refractory to voriconazole and natamycin and successful treatment by topical caspofungin and topical fluconazole [86,87].

\section{Allylamines}

Allylamines interfere with the ergosterol synthesis pathway by reversibly inhibiting squalene epoxidase enzyme. Terbinafine, only one agent in this group, demonstrates excellent in vitro fungicidal activity against many dermatophytes but poor activity against many yeasts (Tables 2 and 3). A retrospective case series of 90 filametous keratitis patients found that topical terbinafine was as effective as topical natamycin but may take longer treatment duration [88].

\begin{tabular}{|c|c|c|c|c|c|}
\hline Study design & Intervention & $\begin{array}{l}\text { Number of } \\
\text { patients }\end{array}$ & Causative organisms & Outcomes criteria & Conclusion \\
\hline $\begin{array}{l}\text { Prospective controlled } \\
\text { clinical trial } \\
\text { Shao Y et al. [44] }\end{array}$ & $\begin{array}{l}\text { Intracameral Amphotericin B } \\
(10 \mu \mathrm{g} / 0.1 \mathrm{ml}) \text { vs Topical } \\
\text { Amphotericin B } 0.15 \%\end{array}$ & 60 & Not revealed & $\begin{array}{l}\text { Clinical response by } \\
\text { healing of the ulcer }\end{array}$ & $\begin{array}{l}\text { Intracameral } \\
\text { Amphotericin B superior } \\
\text { to topical Amphotericin B }\end{array}$ \\
\hline $\begin{array}{l}\text { Clinical trial } \\
\text { Yoon KC et al. [45] }\end{array}$ & 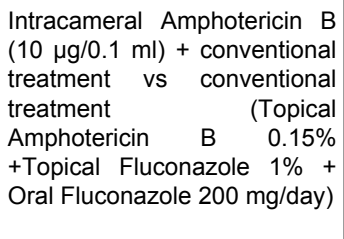 & 31 & $\begin{array}{l}10 \text { Fusarium spp } \\
7 \quad \text { Aspergillus spp } 6 \\
\text { Candida spp } \\
3 \text { Alternaria spp } \\
1 \text { Curvularia spp } \\
4 \text { Unidentified }\end{array}$ & $\begin{array}{l}\text { Clinical response by } \\
\text { healing of the ulcer (time to } \\
\text { disappearance: hypopyon, } \\
\text { epithelial defect closure, } \\
\text { final improvement) }\end{array}$ & $\begin{array}{l}\text { Intracameral } \\
\text { Amphotericin B and } \\
\text { conventional treatment } \\
\text { superior to conventional } \\
\text { treatment }\end{array}$ \\
\hline
\end{tabular}


Citation: Anutarapongpan O, O'Brien TP (2014) Update on Management of Fungal Keratitis. Clin Microbial 3: 168. doi: 10.4172/2327-5073.1000168

Page 4 of 8

\begin{tabular}{|c|c|c|c|c|c|}
\hline $\begin{array}{l}\text { Case series } \\
\text { Yilmaz S et al. [46] }\end{array}$ & $\begin{array}{l}\text { Add intracameral } \\
\text { Amphotericin B }(5 \mu \mathrm{g} / 0.1 \mathrm{ml}) \text { in } \\
\text { cases that did not response to } \\
\text { conventional treatment } \\
\text { (Topical Fluconazole } 0.3 \%, \\
\text { intravenous Fluconazole }+ \\
\text { Oral Itraconazole) }\end{array}$ & 14 eyes in $12 \mathrm{pt}$ & $\begin{array}{l}2 \text { Fusarium spp } \\
4 \quad \text { Aspergillus spp } 6 \\
\text { Candida spp } \\
2 \text { unidentifed hyphae }\end{array}$ & $\begin{array}{l}\text { Clinical response by } \\
\text { healing of the ulcer }\end{array}$ & $\begin{array}{l}\text { Intracameral } \\
\text { Amphotericin B adjuvant } \\
\text { effect in case } \\
\text { unresponsive ro } \\
\text { conventional treatment }\end{array}$ \\
\hline $\begin{array}{l}\text { RCT } \\
\text { Prajna et al. [57] }\end{array}$ & $\begin{array}{l}\text { Topical Econazole 2\% vs } \\
\text { Topical Natamycin } 5 \%\end{array}$ & 112 & $\begin{array}{l}64 \text { Fusarium spp } \\
30 \text { Aspergillus spp } \\
6 \text { Curvularia spp } \\
2 \text { Cladosporium } \\
10 \text { unidentifed hyphae }\end{array}$ & $\begin{array}{l}\text { Clinical response by } \\
\text { healing of the ulcer }\end{array}$ & No difference \\
\hline $\begin{array}{l}\text { Clinical trial } \\
\text { Kalavathy } \mathrm{Cm} \text { et al. [61] }\end{array}$ & $\begin{array}{l}\text { Topical Itraconazole } 1 \% \text { vs } \\
\text { Topical Natamycin } 5 \%\end{array}$ & 100 & $\begin{array}{l}42 \text { Fusarium spp } \\
21 \text { Aspergillus spp } \\
11 \text { Curvularia spp } \\
14 \text { other fungi } \\
12 \text { unidentifed hyphae }\end{array}$ & $\begin{array}{l}\text { Clinical response } \\
\text { healing of the ulcer }\end{array}$ & $\begin{array}{l}\text { Overall no difference but } \\
\text { Natamycin superior in } \\
\text { Fusarium }\end{array}$ \\
\hline $\begin{array}{l}\text { Clinical trial } \\
\text { Mahdy RA et al. [64] }\end{array}$ & $\begin{array}{l}\text { Topical Amphotericin B } 0.05 \% \\
+ \text { Subconjuctival Fluconazole } \\
(1 \mathrm{mg} / 0.5 \mathrm{ml}) \text { vs Topical } \\
\text { Amphotericin B } 0.05 \% \text { alone }\end{array}$ & 48 & $\begin{array}{l}4 \text { Penicillium spp } \\
20 \text { Aspergillus spp } \\
14 \text { Candida spp } \\
10 \text { unidentifed }\end{array}$ & $\begin{array}{l}\text { Clinical response by } \\
\text { healing of the ulcer }\end{array}$ & $\begin{array}{l}\text { Combine therapy superior } \\
\text { to monotherapy }\end{array}$ \\
\hline $\begin{array}{l}\text { RCT } \\
\text { Prajna NV et al. [76] }\end{array}$ & $\begin{array}{l}\text { Topical } 1 \% \text { Voriconazole vs } \\
\text { Topical } 5 \% \text { Natamycin }\end{array}$ & 120 & $\begin{array}{l}44 \text { Fusarium spp } \\
19 \text { Aspergillus spp } \\
39 \text { Other filamentous fungi }\end{array}$ & $\begin{array}{l}1^{\text {st }} \text { BCVA } \\
2^{\text {nd }} \text { scar size, perforation }\end{array}$ & $\begin{array}{l}\text { No significant differences } \\
\text { in visual acuity, } \\
\text { scar size and perforations } \\
\text { between the two groups }\end{array}$ \\
\hline $\begin{array}{l}\text { Clinical trial } \\
\text { Arora R et al. [77] }\end{array}$ & $\begin{array}{l}\text { Topical } 1 \% \text { Voriconazole vs } \\
\text { Topical } 5 \% \text { Natamycin }\end{array}$ & 30 & $\begin{array}{l}13 \text { Aspergillus spp } \\
12 \text { Curvularia spp } \\
5 \text { Other filamentous fungi }\end{array}$ & $\begin{array}{l}\text { Clinical response by } \\
\text { healing of the ulcer }\end{array}$ & No difference \\
\hline $\begin{array}{l}\text { Retrospective review } \\
\text { Ramakrishnan T et al. [81] }\end{array}$ & $\begin{array}{l}\text { Topical } 1 \% \text { Voriconazole, Oral } \\
\text { voriconazole }(400 \mathrm{mg}) \text {, } \\
\text { Topical } 5 \% \quad \text { Natamycin, } \\
\text { Intrastromal Voriconazole, } \\
\text { Intracameral Voriconazole }\end{array}$ & 26 & $\begin{array}{l}7 \text { Fusarium spp } \\
3 \text { Aspergillus spp } \\
4 \text { Candida spp } \\
3 \text { Scedosporium Spp } \\
9 \text { other fungi }\end{array}$ & $\begin{array}{l}\text { Clinical response by } \\
\text { healing of the ulcer }\end{array}$ & $\begin{array}{l}\text { Successful management } \\
\text { in } 50 \% \text { of cases }\end{array}$ \\
\hline $\begin{array}{l}\text { RCT } \\
\text { Parchand S et al. [78] }\end{array}$ & $\begin{array}{l}\text { Gr1:Topical } 1 \% \text { Voriconazole } \\
+ \text { Oral voriconazole }(400 \mathrm{mg}) \\
\text { Gr2: Topical } 5 \% \text { Natamycin+ } \\
\text { Oral voriconazole }(400 \mathrm{mg}) \\
\text { Gr3: Topical } 5 \% \text { Natamycin+ } \\
\text { Oral itraconazole }(400 \mathrm{mg})\end{array}$ & 45 & $\begin{array}{l}6 \text { Fusarium spp } \\
8 \text { Aspergillus spp } \\
2 \text { Curvularia spp } \\
1 \text { Acremonium Spp } \\
28 \text { unidentifed }\end{array}$ & $\begin{array}{l}1^{\text {st }} \text { Clinical response by } \\
\text { healing of the ulcer } \\
2^{\text {nd }} \text { Corneal opacity, BCVA }\end{array}$ & No difference \\
\hline $\begin{array}{l}\text { RCT } \\
\text { Prajna NV et al. [79] }\end{array}$ & $\begin{array}{l}\text { Topical } 1 \% \text { Voriconazole vs } \\
\text { Topical } 5 \% \text { Natamycin }\end{array}$ & 368 & $\begin{array}{l}128 \text { Fusarium spp } \\
54 \text { Aspergillus spp } \\
141 \text { Other filamentous } \\
\text { fungi }\end{array}$ & $\begin{array}{l}1^{\text {st }} \text { BCVA } \\
2^{\text {nd }} \text { perforation and/or PKP }\end{array}$ & $\begin{array}{l}\text { Topical natamycin } \\
\text { superior to topical } \\
\text { voriconazole }\end{array}$ \\
\hline $\begin{array}{l}\text { RCT } \\
\text { Sharma } \mathrm{N} \text { et al. [80] }\end{array}$ & $\begin{array}{lrr}\text { Topical } & 1 \% & \text { Voriconazole } \\
\text { +Topical } & 5 \% & \text { Natamycin vs } \\
\text { Intrastromal } & \text { Voriconazole } \\
\text { +Topical } 5 \% \text { Natamycin }\end{array}$ & 40 & $\begin{array}{l}7 \text { Fusarium spp } \\
12 \text { Aspergillus spp } \\
5 \text { Curvularia spp } \\
1 \text { Alternaria } \\
15 \text { No growth }\end{array}$ & $\begin{array}{l}1^{\text {st }} \text { BSCVA } \\
2^{\text {nd }} \text { time to healing and the } \\
\text { size of the scar }\end{array}$ & $\begin{array}{l}\text { Topical Voriconazole } \\
\text { seem to be useful adjunct } \\
\text { to Natamycin }\end{array}$ \\
\hline
\end{tabular}

Table 2: Clinical trials for treatment of fungal keratitis showing results of different antifungal medications. 
Citation: Anutarapongpan O, O'Brien TP (2014) Update on Management of Fungal Keratitis. Clin Microbial 3: 168. doi: 10.4172/2327-5073.1000168

Page 5 of 8

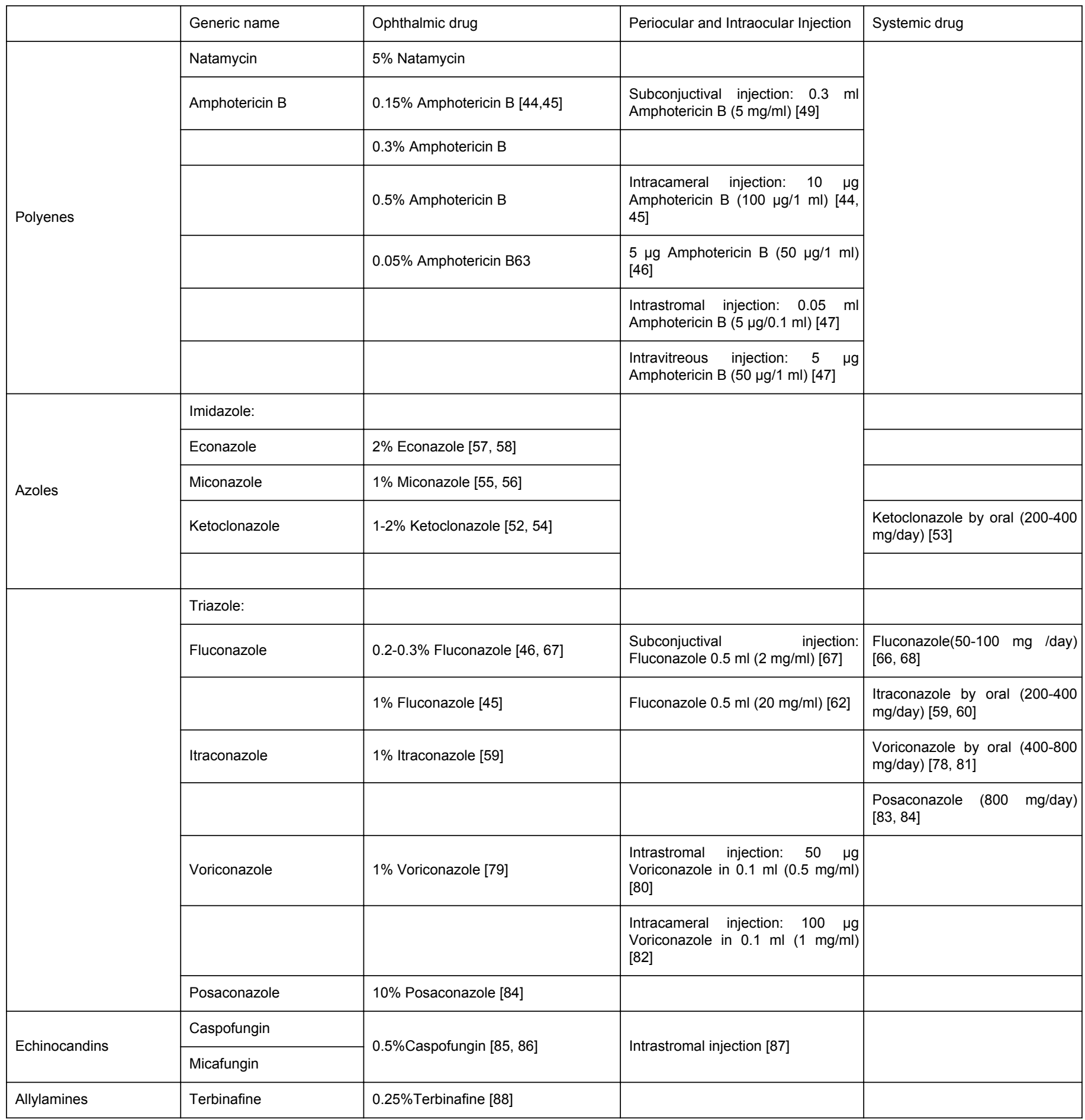

Table 3: Summery of Antifungal therapy in Fungal keratitis.

\section{Corneal collagen cross linking}

Corneal collagen cross linking is an exciting new technique using the photosensitizer riboflavin (vitamin B2) and ultraviolet A (UVA) irradiation at $370 \mathrm{~nm}$ to induce increasing corneal tissue strength and rigidity [89]. Originally, this intervention was introduced for treatment of corneal ectasias such as keratoconus. The effects of UV irradiation onto riboflavin saturated cornea generates oxygen and superoxide anion radicals [90] that induce intra and/or interhelical collagen cross-links, These activated radicals could inactivate microbial pathogens [91]. Several studies demonstrated in vitro antimicrobial activity of corneal collagen cross linking against varies pathogens [92-96]. Anwar et al. first reported successful treatment of Aspergillus keratitis with UVA-riboflavin CXL, along with antifungal 
treatment in human eye [97]. Saglik et al. reported Riboflavin/UVA treatment to be useful as a coadjuvant to topical voriconazole in fungal keratitis [98]. Zhiwei $\mathrm{Li}$ et al. reported 6 cases of fungal keratitis (Aspergillus spp, Fusarium spp) successfully treated with Riboflavin/UVA and antimicrobial therapy [99]. Riboflavin/UVA adjuvant to antimicrobial therapy seems to be a promising technique for management of fungal keratitis. Further randomized clinical trials are required to establish the risks and benefits of CXL.

\section{Corneal debridement}

Most antifungal agents have poor bioavailability and limited penetration into deeper layers of the cornea, especially in cases of fungal keratitis with intact corneal epithelium. Serial debridements of corneal epithelium seem to be useful to increase drug penetration. A recent survey revealed that ophthalmologists rescrape during the treatment course of fungal keratitis with natamycin more than with voriconazole [87]. In contrast, one randomized double-masked control trial included 120 patients randomized to receive either topical natamycin or topical voriconazole and either had repeated scraping of the epithelium or not. This comparison failed to demonstrate a benefit to this intervention but showed worse outcomes in the scraping group [76].

\section{Surgical treatment}

Despite currently available antifungal drug therapy, severe fungal infections may lead to acute perforation, scleritis, endophthalmitis, and blindness. Surgical treatments try to remove infectious elements and also necrotic tissue and other debris, which may hinder complete healing of the lesion. In cases of descemetocele, corneal perforation, or recalcitrant fungal keratitis not responsive to maximum medication therapy, surgical management should be considered. Which specific surgical procedure depends on severity of disease. Permanent conjunctival flaps $[100,101]$ or amniotic membrane transplantation [102], and use of tissue adhesives [100,103] are some of the other surgical methods used for the treatment of various types of fungal corneal ulcers. Penetrating keratoplasty is major surgical procedure to restore anatomical integrity and eradicate infection, but recurrent fungal infection can occur. Hypopyon, corneal perforation, corneal infection extending to limbus, or lens infection are major risk factors for recurrence of infection [104]. In some cases where infection does not extend through the entire thickness of the cornea, lamellar keratoplasty can be considered [105].

\section{Conclusion}

Fungal keratitis is a leading cause of visual loss and blindness worldwide. This condition remains a diagnostic challenge and a difficult management problem for treating ophthalmologists. Awareness of this condition together with knowledge of risk factors is an important key for early diagnosis. As there is often delay or misdiagnosis of fungal keratitis, aggressive diagnostic efforts and maximal therapeutic strategies should be exercised in cases having high suspicion or in failure of keratitis to respond to conventional adequate antibacterial therapy. Progress in research and development of antifungal agents for application to oculomycoses has been slow. Current antifungal agents are limited in their efficacy due to poor solubility, limited penetration and intrinsic toxicities. New areas of research and development into both diagnostic and therapeutic methods may lead to prompt initiation of specific treatment and improved prognosis with better management of the fungal infection.

\section{References}

1. Whitcher JP, Srinivasan M, Upadhyay MP (2001) Corneal blindness: a global perspective. Bull World Health Organ 79: 214-221.

2. Thomas PA (1994) Mycotic keratitis--an underestimated mycosis. J Med Vet Mycol 32: 235-256.

3. Wong TY, Ng TP, Fong KS, Tan DT (1997) Risk factors and clinical outcomes between fungal and bacterial keratitis: a comparative study. CLAO J 23: 275-281.

4. Ng JK, Fraunfelder FW, Winthrop KL (2013) Review and Update on the Epidemiology, Clinical Presentation, Diagnosis, and Treatment of Fungal Keratitis. Curr Fungal Infect Rep 7: 293-300.

5. Thomas PA, Geraldine P (1992) Fungal keratitis due to Fusarium and other fungi. J Myco Med 2: 121-131.

6. Sharma S (2012) Diagnosis of fungal keratitis: current options. Expert Opin Med Diagn 6: 449-455.

7. Thomas PA, Kaliamurthy J (2013) Mycotic keratitis: epidemiology, diagnosis and management. Clin Microbiol Infect 19: 210-220.

8. Alfonso EC, Galor A, Miller D (1990) Fungal keratitis. In: Krachmer JH,Mannis MJ, Holland EJ (eds), Cornea. (3rdedn), Raven Press, New York, pp: 1009-1022.

9. Badiee P, Nejabat M, Alborzi A, Keshavarz F, Shakiba E (2010) Comparative study of Gram stain, potassium hydroxide smear, culture and nested PCR in the diagnosis of fungal keratitis. Ophthalmic Res 44: 251-256.

10. Gopinathan U, Sharma S, Garg P, Rao GN (2009) Review of epidemiological features, microbiological diagnosis and treatment outcome of microbial keratitis: experience of over a decade. Indian J Ophthalmol 57: 273-279.

11. Bharathi MJ, Ramakrishnan R, Meenakshi R, Mittal S, Shivakumar C, et al. (2006) Microbiological diagnosis of infective keratitis: comparative evaluation of direct microscopy and culture results. Br J Ophthalmol 90: 1271-1276.

12. Zhang W, Yang H, Jiang L, Han L, Wang L (2010) Use of potassium hydroxide, Giemsa and calcofluor white staining techniques in the microscopic evaluation of corneal scrapings for diagnosis of fungal keratitis. J Int Med Res 38: 1961-1967.

13. Jain AK, Bansal R, Felcida V, Rajwanshi A (2007) Evaluation of impression smear in the diagnosis of fungal keratitis. Indian J Ophthalmol 55: 33-36.

14. Bethke W (2013) Meeting the Challenge of Fungal Keratitis. Review of Ophthalmology. 20: 42.

15. Sridhar MS (2005) Diagnosis and Management of Microbial Keratitis. CME Series-11. All india ophthalmological society, New Delhi.

16. Alexandrakis G, Haimovici R, Miller D, Alfonso EC (2000) Corneal biopsy in the management of progressive microbial keratitis. Am J Ophthalmol 129: 571-576.

17. Naumann G, Green WR, Zimmerman LE (1967) A histopathologic study of 73 cases. Am J Ophthalmol 64: 668-682.

18. Kompa S, Langefeld S, Kirchhof B, Schrage N (1999) Corneal biopsy in keratitis performed with the microtrephine. Graefes Arch Clin Exp Ophthalmol 237: 915-919.

19. Kim JH, Yum JH, Lee D, Oh SH (2008) Novel technique of corneal biopsy by using a femtosecond laser in infectious ulcers. Cornea 27: 363-365.

20. Yoo SH, Kymionis GD, O'Brien TP, Ide T, Culbertson W, et al. (2008) Femtosecond-assisted diagnostic corneal biopsy (FAB) in keratitis. Graefes Arch Clin Exp Ophthalmol 246: 759-762.

21. Pawley JB (2006) Handbook of biological confocal microscopy. (3rdedn), Springer, Berlin.

22. Erie JC, McLaren JW, Patel SV (2009) Confocal microscopy in ophthalmology. Am J Ophthalmol 148: 639-646.

23. Vaddavalli PK, Garg P, Sharma S, Sangwan VS, Rao GN, et al. (2011) Role of confocal microscopy in the diagnosis of fungal and acanthamoeba keratitis. Ophthalmology 118: 29-35. 
24. Kanavi MR, Javadi M, Yazdani S, Mirdehghanm S (2007) Sensitivity and specificity of confocal scan in the diagnosis of infectious keratitis. Cornea 26: 782-786.

25. Kumar RL, Cruzat A, Hamrah P (2010) Current state of in vivo confocal microscopy in management of microbial keratitis. Semin Ophthalmol 25: 166-170.

26. Ferrer C, Alió JL (2011) Evaluation of molecular diagnosis in funga keratitis. Ten years of experience. J Ophthalmic Inflamm Infect 1: 15-22.

27. Farhatullah S, Kaza S, Athmanathan S, Garg P, Reddy SB, et al. (2004) Diagnosis of herpes simplex virus-1 keratitis using Giemsa stain, immunofluorescence assay, and polymerase chain reaction assay on corneal scrapings. Br J Ophthalmol 88: 142-144.

28. Ikeda Y, Miyazaki D, Yakura K, Kawaguchi A, Ishikura R, et al. (2012) Assessment of real-time polymerase chain reaction detection of Acanthamoeba and prognosis determinants of Acanthamoeba keratitis. Ophthalmology 119: 1111-1119.

29. Itahashi M, Higaki S, Fukuda M, Shimomura Y (2010) Detection and quantification of pathogenic bacteria and fungi using real-time polymerase chain reaction by cycling probe in patients with corneal ulcer. Arch Ophthalmol 128: 535-540.

30. Ge Z, Qing Y, Zicheng S, Shiying S (2013) Rapid and sensitive diagnosis of Acanthamoeba keratitis by loop-mediated isothermal amplification. Clin Microbiol Infect 19: 1042-1048.

31. Reddy AK, Balne PK, Reddy RK, Mathai A, Kaur I (2011) Loop-mediated isothermal amplification assay for the diagnosis of retinitis caused by herpes simplex virus-1. Clin Microbiol Infect 17: 210-213.

32. Kuo MT, Chang HC, Cheng CK, Chien CC, Fang PC, et al. (2012) A highly sensitive method for molecular diagnosis of fungal keratitis: a dot hybridization assay. Ophthalmology 119: 2434-2442.

33. Eleinen KG, Mohalhal AA, Elmekawy HE, Abdulbaki AM, Sherif AM, et al. (2012) Polymerase chain reaction-guided diagnosis of infective keratitis - a hospital-based study. Curr Eye Res 37: 1005-1011.

34. Embong Z, Wan Hitam WH, Yean CY, Rashid NH, Kamarudin B, et al. (2008) Specific detection of fungal pathogens by 18 S rRNA gene PCR in microbial keratitis. BMC Ophthalmol 8: 7.

35. Kim E, Chidambaram JD, Srinivasan M, Lalitha P, Wee D, et al. (2008) Prospective comparison of microbial culture and polymerase chain reaction in the diagnosis of corneal ulcer. Am J Ophthalmol 146: 714-723, 723 .

36. Reiss E, Tanaka K, Bruker G, Chazalet V, Coleman D, et al. (1998) Molecular diagnosis and epidemiology of fungal infections. Med Mycol 36 Suppl 1: 249-257.

37. Camargo ZP, Unterkircher C, Travassos LR (1989) Identification of antigenic polypeptides of Paracoccidioides brasiliensis by immunoblotting. J Med Vet Mycol 27: 407-412.

38. Holmes AR, Lee YC, Cannon RD, Jenkinson HF, Shepherd MG (1992) Yeast-specific DNA probes and their application for the detection of Candida albicans. J Med Microbiol 37: 346-351.

39. Zhao G, Zhai H, Yuan Q, Sun S, Liu T, et al. (2014) Rapid and sensitive diagnosis of fungal keratitis with direct PCR without template DNA extraction. Clin Microbiol Infect.

40. Georgopapadakou NH, Walsh TJ (1994) Human mycoses: drugs and targets for emerging pathogens. Science 264: 371-373.

41. Brajtburg J, Powderly WG, Kobayashi GS, Medoff G (1990) Amphotericin B: current understanding of mechanisms of action. Antimicrob Agents Chemother 34: 183-188.

42. Velez JD, Allendoerfer R, Luther M, Rinaldi MG, Graybill JR (1993) Correlation of in vitro azole susceptibility with in vivo response in a murine model of cryptococcal meningitis. J Infect Dis 168: 508-510.

43. Thomas PA (2003) Fungal infections of the cornea. Eye (Lond) 17: 852-862.

44. Shao Y, Yu Y, Pei CG, Tan YH, Zhou Q, et al. (2010) Therapeutic efficacy of intracameral amphotericin B injection for 60 patients with keratomycosis. Int J Ophthalmol 3: 257-260.
45. Yoon KC, Jeong IY, Im SK, Chae HJ, Yang SY (2007) Therapeutic effect of intracameral amphotericin B injection in the treatment of fungal keratitis. Cornea 26: 814-818.

46. Yilmaz S, Ture M, Maden A (2007) Efficacy of intracameral amphotericin B injection in the management of refractory keratomycosis and endophthalmitis. Cornea 26: 398-402.

47. Garcia-Valenzuela E, Song CD (2005) Intracorneal injection of amphothericin B for recurrent fungal keratitis and endophthalmitis. Arch Ophthalmol 123: 1721-1723.

48. Qu L, Li L, Xie H (2014) Toxicity and pharmacokinetics of intrastromal injection of amphotericin B in a rabbit model. Curr Eye Res 39: 340-347.

49. Carrasco MA, Genesoni G (2011) Treatment of severe fungal keratitis with subconjunctival amphotericin B. Cornea 30: 608-611.

50. Bell RW, Ritchey JP (1973) Subconjunctival nodules after amphotericin B injection. Medical therapy for Aspergillus corneal ulcer. Arch Ophthalmol 90: 402-404.

51. Vanden Bossche H, Marichal P, Gorrens J, Geerts H, Janssen PA (1988) Mode of action studies. Basis for the search of new antifungal drugs. Ann N Y Acad Sci 544: 191-207.

52. Torres MA, Mohamed J, Cavazos-Adame H, Martinez LA (1985) Topical ketoconazole for fungal keratitis. Am J Ophthalmol 100: 293-298.

53. Garg P, Gopinathan U, Choudhary K, Rao GN (2000) Keratomycosis: clinical and microbiologic experience with dematiaceous fungi. Ophthalmology 107: 574-580.

54. Rajasekaran J, Thomas PA, Srinivasan R (1987) Ketoconazole in keratomycosis. In Blodi F, Brancato R, Cristini G (eds), Acta XXV Concilium Ophthalmologicum. Kugler Ghedini, Amsterdam pp: 2462-2467.

55. Fitzsimons R, Peters AL (1986) Miconazole and ketoconazole as a satisfactory first-line treatment for keratomycosis. Am J Ophthalmol 101: 605-608.

56. Foster CS (1981) Miconazole therapy for keratomycosis. Am J Ophthalmol 91: 622-629.

57. Prajna NV, John RK, Nirmalan PK, Lalitha P, Srinivasan M (2003) A randomised clinical trial comparing 2\% econazole and 5\% natamycin for the treatment of fungal keratitis. Br J Ophthalmol 87: 1235-1237.

58. Prajna NV, Nirmalan PK, Mahalakshmi R, Lalitha P, Srinivasan M (2004) Concurrent use of $5 \%$ natamycin and $2 \%$ econazole for the management of fungal keratitis. Cornea 23: 793-796.

59. Massry GG, Hornblass A, Harrison W (1996) Itraconazole in the treatment of orbital aspergillosis. Ophthalmology 103: 1467-1470.

60. Thomas PA, Abraham DJ, Kalavathy CM, Rajasekaran J (1988) Oral itraconazole therapy for mycotic keratitis. Mycoses 31: 271-279.

61. Kalavathy CM, Parmar P, Kaliamurthy J, Philip VR, Ramalingam MD, et al. (2005) Comparison of topical itraconazole $1 \%$ with topical natamycin $5 \%$ for the treatment of filamentous fungal keratitis. Cornea 24: 449-452.

62. Dev S, Rajaraman R, Raghavan A (2006) Severe fungal keratitis treated with subconjunctival fluconazole. Am J Ophthalmol 141: 783.

63. Gong H, Gong X2 (2013) Combined application of 5\% natamycin and $0.2 \%$ fluconazole for the treatment of fungal keratitis. Eye Sci 28: 84-87.

64. Mahdy RA, Nada WM, Wageh MM (2010) Topical amphotericin B and subconjunctival injection of fluconazole (combination therapy) versus topical amphotericin B (monotherapy) in treatment of keratomycosis. J Ocul Pharmacol Ther 26: 281-285.

65. Mahdy RA, Nada WM, Wageh MM, Kader MA, Saleh MM, et al. (2010) Assessment safety and efficacy of a combination therapy of topical amphotericin B and subconjunctival fluconazole for the treatment of fungal keratitis. Cutan Ocul Toxicol 29: 193-197.

66. Rao SK, Madhavan HN, Rao G, Padmanabhan P (1997) Fluconazole in filamentous fungal keratitis. Cornea 16: 700.

67. Sonego-Krone S, Sanchez-Di Martino D, Ayala-Lugo R, Torres-Alvariza $\mathrm{G}$, Ta CN, et al. (2006) Clinical results of topical fluconazole for the treatment of filamentous fungal keratitis. Graefes Arch Clin Exp Ophthalmol 244: 782-787. 
68. Thakar M (1994) Oral fluconazole therapy for keratomycosis. Acta Ophthalmol (Copenh) 72: 765-767.

69. Hariprasad SM, Mieler WF, Holz ER, Gao H, Kim JE, et al. (2004) Determination of vitreous, aqueous, and plasma concentration of orally administered voriconazole in humans. Arch Ophthalmol 122: 42-47.

70. Vemulakonda GA, Hariprasad SM, Mieler WF, Prince RA, Shah GK, et al. (2008) Aqueous and vitreous concentrations following topical administration of $1 \%$ voriconazole in humans. Arch Ophthalmol 126: $18-22$.

71. Lalitha P, Sun CQ2, Prajna NV, Karpagam R, Geetha M, et al. (2014) In vitro susceptibility of filamentous fungal isolates from a corneal ulcer clinical trial. Am J Ophthalmol 157: 318-326.

72. Hariprasad SM, Mieler WF, Lin TK, Sponsel WE, Graybill JR (2008) Voriconazole in the treatment of fungal eye infections: a review of current literature. Br J Ophthalmol 92: 871-878.

73. Prakash G, Sharma N, Goel M, Titiyal JS, Vajpayee RB (2008) Evaluation of intrastromal injection of voriconazole as a therapeutic adjunctive for the management of deep recalcitrant fungal keratitis. Am J Ophthalmol 146: 56-59.

74. Siatiri H, Daneshgar F, Siatiri N, Khodabande A (2011) The effects of intrastromal voriconazole injection and topical voriconazole in the treatment of recalcitrant Fusarium keratitis. Cornea 30: 872-875.

75. Sharma N, Agarwal P, Sinha R, Titiyal JS, Velpandian T, et al. (2011) Evaluation of intrastromal voriconazole injection in recalcitrant deep fungal keratitis: case series. Br J Ophthalmol 95: 1735-1737.

76. Prajna NV, Mascarenhas J, Krishnan T, Reddy PR, Prajna L, et al. (2010) Comparison of natamycin and voriconazole for the treatment of fungal keratitis. Arch Ophthalmol 128: 672-678.

77. Arora R, Gupta D, Goyal J, Kaur R (2011) Voriconazole versus natamycin as primary treatment in fungal corneal ulcers. Clin Experiment Ophthalmol 39: 434-440.

78. Parchand S, Gupta A, Ram J, Gupta N, Chakrabarty A (2012) Voriconazole for fungal corneal ulcers. Ophthalmology 119: 1083.

79. Prajna NV, Krishnan T, Mascarenhas J, Rajaraman R, Prajna L, et al. (2013) The mycotic ulcer treatment trial: a randomized trial comparing natamycin vs voriconazole. JAMA Ophthalmol 131: 422-429.

80. Sharma N, Chacko J, Velpandian T, Titiyal JS, Sinha R, et al. (2013) Comparative evaluation of topical versus intrastromal voriconazole as an adjunct to natamycin in recalcitrant fungal keratitis. Ophthalmology 120: 677-681.

81. Ramakrishnan T, Constantinou M, Jhanji V, Vajpayee RB (2013) Factors affecting treatment outcomes with voriconazole in cases with fungal keratitis. Cornea 32: 445-449.

82. Shen YC, Wang CY, Tsai HY, Lee HN (2010) Intracameral voriconazole injection in the treatment of fungal endophthalmitis resulting from keratitis. Am J Ophthalmol 149: 916-921.

83. Tu EY, McCartney DL, Beatty RF, Springer KL, Levy J, et al. (2007) Successful treatment of resistant ocular fusariosis with posaconazole (SCH-56592). Am J Ophthalmol 143: 222-227.

84. Sponsel WE, Graybill JR, Nevarez HL, Dang D (2002) Ocular and systemic posaconazole(SCH-56592) treatment of invasive Fusarium solani keratitis and endophthalmitis. Br J Ophthalmol 86: 829-830.

85. Hurtado-Sarrió M, Duch-Samper A, Cisneros-Lanuza A, Díaz-Llopis M, Peman-Garcíia J, et al. (2010) Successful topical application of caspofungin in the treatment of fungal keratitis refractory to voriconazole. Arch Ophthalmol 128: 941-942.

86. Tu EY (2009) Alternaria keratitis: clinical presentation and resolution with topical fluconazole or intrastromal voriconazole and topical caspofungin. Cornea 28: 116-119.
87. Neoh CF, Leung L, Vajpayee RB, Stewart K, Kong DC (2011) Treatment of Alternaria keratitis with intrastromal and topical caspofungin in combination with intrastromal, topical, and oral voriconazole. Ann Pharmacother 45: e24.

88. Liang QF, Jin XY, Wang XL, Sun XG (2009) Effect of topical application of terbinafine on fungal keratitis. Chin Med J (Engl) 122: 1884-1888.

89. Spoerl E, Huhle M, Seiler T (1998) Induction of cross-links in corneal tissue. Exp Eye Res 66: 97-103.

90. Wollensak G (2006) Crosslinking treatment of progressive keratoconus: new hope. Curr Opin Ophthalmol 17: 356-360.

91. Kumar V, Lockerbie O, Keil SD, Ruane PH, Platz MS, et al. (2004) Riboflavin and UV-light based pathogen reduction: extent and consequence of DNA damage at the molecular level. Photochem Photobiol 80: 15-21.

92. Martins SA, Combs JC, Noguera G, Camacho W, Wittmann P, et al. (2008) Antimicrobial efficacy of riboflavin/UVA combination $(365 \mathrm{~nm})$ in vitro for bacterial and fungal isolates: a potential new treatment for infectious keratitis. Invest Ophthalmol Vis Sci 49: 3402-3408.

93. Schrier A, Greebel G, Attia H, Trokel S, Smith EF (2009) In vitro antimicrobial effi cacy of ribofl avin and ultraviolet light on Staphylococcus aureus, methicillin-resistant Staphylococcus aureus, and Pseudomonas aeruginosa. J Refract Surg 25: S799-S802.

94. Makdoumi K, Bäckman A, Mortensen J, Crafoord S (2010) Evaluation of antibacterial efficacy of photo-activated riboflavin using ultraviolet light (UVA). Graefes Arch Clin Exp Ophthalmol 248: 207-212.

95. Sauer A, Letscher-Bru V, Speeg-Schatz C, Touboul D, Colin J, et al. (2010) In vitro efficacy of antifungal treatment using riboflavin/UV-A $(365 \mathrm{~nm})$ combination and amphotericin B. Invest Ophthalmol Vis Sci 51: 3950-3953.

96. del Buey MA, Cristóbal JA, Casas P, Goñi P, Clavel A, et al. (2012) Evaluation of in vitro efficacy of combined riboflavin and ultraviolet a for Acanthamoeba isolates. Am J Ophthalmol 153: 399-404.

97. Anwar HM, El-Danasoury AM, Hashem AN (2011) Corneal collagen crosslinking in the treatment of infectious keratitis. Clin Ophthalmol 5: 1277-1280.

98. Saglk A, UÃ§akhan OO, Kanpolat A (2013) Ultraviolet A and riboflavin therapy as an adjunct in corneal ulcer refractory to medical treatment. Eye Contact Lens 39: 413-415.

99. Li Z, Jhanji V, Tao X, Yu H, Chen W, et al. (2013) Riboflavin/ultravoilet light-mediated crosslinking for fungal keratitis. Br J Ophthalmol 97: 669-671.

100. Agrawal V, Biswas J, Madhavan HN, Mangat G, Reddy MK, et al. (1994) Current perspectives in infectious keratitis. Indian J Ophthalmol 42: 171-192.

101. Alino AM, Perry HD, Kanellopoulos AJ, Donnenfeld ED, Rahn EK (1998) Conjunctival flaps. Ophthalmology 105: 1120-1123.

102. Forster RK (1994) Fungal keratitis and conjunctivitis: clinical aspects. In: Smolin G, Thoft RA (eds), The Cornea: Scientific Foundations and Clinical Practice. (3rdedn), Little, Brown \& Co., Boston, pp: 239-252.

103. Kim JS, Kim JC, Hahn TW, Park WC (2001) Amniotic membrane transplantation in infectious corneal ulcer. Cornea 20: 720-726.

104. Shi W, Wang T, Xie L, Li S, Gao H, et al. (2010) Risk factors, clinical features, and outcomes of recurrent fungal keratitis after corneal transplantation. Ophthalmology 117: 890-896.

105. Xie L, Shi W, Liu Z, Li S (2002) Lamellar keratoplasty for the treatment of fungal keratitis. Cornea 21: 33-37. 